\title{
Studies of Nematocysts
}

$\mathrm{I}^{\mathrm{N}}$ a work of 700 pages (Travaux de la Station Zoologique de Wimereux, 10 and 11. Paris: Laboratoire d'évolution des êtres organisés, 1934. 125 frs. each) Robert Weill describes the results of his detailed observations on the Cnidaria with special reference to their nematocysts. His investigations have been made largely on fresh material derived from 113 species of coelenterates.

A short historical summary is followed by a careful description of a nematocyst-an ovoid capsule with a circular opening at the narrow end closed by an operculum, and here the wall of the capsule is continuous with the tube enclosed in the capsule; the basal part of the tube is generally wider and straight, the distal part narrow and spirally coiled, and both parts of the tube have on the inner surface numerous spines inserted in groups of three. The tube is discharged through the terminal aperture and the remains of the operculum are usually demonstrable; at the same time the refringency of the capsule is lost, for its contents have been expelled. The author describes the wide variations in size of the nematocysts, from $5 \mu$ in length in some Alcyonaria to $1 \cdot 12$ $\mathrm{mm}$. in length in the siphonophore Halistemma.

Weill classifies the different types of nematocysts into those with closed tube, of which there are three kinds, and those in which the tube is open at its tip, of which fourteen kinds are recognised. $\mathrm{He}$ discusses the question of nerve supply to the nematocyst cell and concludes provisionally that a nervous connexion is unlikely. The author is very decided that the discharge of the tube is not by its unbending, like a spring, but by its devagination, for by retarding the process the stages of extroversion can be followed under the microscope. The tube is longer and wider after discharge-it may be doubled in length-hence its wall is elastic and in the undischarged nematocyst is in a state of disequilibrium. After discussing the mechanism of discharge, the author, accepts the view of Iwanzoff (1896) that the discharge is due to swelling of the contents of the capsule. Discharge can be brought about only in presence of fluid which penetrates the capsule, but what determines the endosmosis is not yet known.

The author describes his observations on the development of nematocysts, and traces the migrations of the nematocyst cells, for example, in the Lucernaridæ, from their origin in thickened ectoderm at the edge of the subumbrella to the tentacular knobs. Fully formed nematocysts appear to remain functional indefinitely. About three hundred pages are devoted to a consideration of the taxonomic value of the cnidome, that is, the ensemble of the nematocysts presented by a particular species of cœlenterate. In discussing the Gymnoblastea, considered to be an artificial and heterogeneous group, Weill considers that Hydra represents not a primitive but one of the most complex genera, and should be placed near the Tubulariidæ. The study of the cnidome confirms the distinction between the Milleporidæ, which are allied to Gymnoblastea, and the Stylasteridæ, which are near the Calyptoblastea. Incidentally, the author does not accept Willey's observation that the filament of a discharged nematocyst of Millepora can be withdrawn or retracted. In their cnidome the Scyphozoa approximate more to the Hydrozoa than to the Anthozoa. Alcyonaria have a homogeneous cnidome different from that of Zoantharia. The bearing of the cnidome on the classification of anemones and corals is discussed.

This important monograph concludes with an extensive bibliography and an index of the genera and species referred to in the work.

\section{British Association at Dublin in I835}

$\mathrm{T}$ HE fifth meeting of the British Association was held at Dublin during the week beginning August 10, 1835. The president was Dr. Bartholomew Lloyd (1772-1837), provost of Trinity College, Dublin, the vice-presidents, Lord Oxonantown and the Rev. William Whewell, while the local secretaries were William Rowan Hamilton (1805-1865), Astronomer Royal of Ireland, and Humphrey Lloyd (1800-1881), Erasmus Smith professor of natural and experimental philosophy. The scientific proceedings were dealt with in six sections: (I) Mathematies and Physics ; (II) Chemistry and Mineralogy ; (III) Geelogy and Geography; (IV) Zoology and Botany; (V) Anatomy and Medicine; and (VI) Statistics, to which was added during the meeting the subsection on Mechanical Science Applied to the Arts. The meeting was largely attended, and there was a great deal of entertaining. Among the most famous men of science who were present were Sedgwick, Ross, Franklin, Agassiz, Dalton, Lardner, Babbage,
Murchison, Rennie, Sabine, Wheatstone, Scott Russell and Eaton Hodgkinson. During the meeting the University conferred degrees upon William Smith, Sir Thomas Brisbane, Francis Baily, Prof. Moll and M. Agassiz.

Official reports of the proceedings were communicated to the editors of the Philosophical Magazine, and the daily papers gave accounts of some of the meetings. Perhaps the liveliest reports of the meeting were those published in the Athenoeum of August 15, 1835 , and succeeding issues, and from these a few extracts have been taken. The first portion of the report said: "The British Association has received, as we anticipated, a great accession to its members in Dublin, though many who intended to join it have been detained by their Parliamentary duties and by the Assizes. Still so many candidates presented themselves that the local council was compelled to place some restrictions on admission and to refuse, unless under special circumstances, all 